\begin{tabular}{|c|c|}
\hline Заключение. & газов \\
\hline транспортируемых & $\mathrm{oc}$ \\
\hline компонентный & \\
\hline углеводородного & ратура \\
\hline диагностирующим признаком образования жидких & 1. Гриченко А.И. Исследование влияния воды \\
\hline содержания & на фазовые превращен \\
\hline компонентов в смеси в условиях промыслового & \\
\hline ранспортировки природных и попул & Х., Аметов И.М., Ба \\
\hline газов, а также их смесей. Неаддитивный хара & ычи природных газ \\
\hline $\begin{array}{llll}\text { процессов, } & \text { происходящих } & \text { при } & \text { смещении } \\
\text { природных и попутных газов, } & \text { можно объяснить }\end{array}$ & $\begin{array}{l}\text { pa, } 1987,414 \text { c. } \\
\text { 3. Влияние обводнения многопластовь }\end{array}$ \\
\hline выделением жидкой фазы и возникновением & газовых и газоконденсатных месторождений \\
\hline \begin{tabular}{lccc} 
ретроградных & явлений & в & \multicolumn{2}{c}{ трубопроводе. } \\
Характеристикой & обратного & испарения
\end{tabular} & $\begin{array}{l}\text { разработку / Г.В.Рассохин, И.А.Лео } \\
\text { В.И.Петренко и др., М.Недра , 1973,262с. }\end{array}$ \\
\hline $\begin{array}{l}\text { трубопроводе является возрастание значений } \\
\text { ранга, а снижение ранга является показателем } \\
\text { обратной конденсации, т. е. накоплении жидкой } \\
\text { фазы в трубопроводе. }\end{array}$ & $\begin{array}{l}\text { 4. Исмаилов К.К. Диагностирование режим } \\
\text { работы нефтяного пласта по компонентно» } \\
\text { составу газа. Изв. ВУЗов «Нефть и газ», } 1982 \text {, № } \\
\text { c. } 80-81 .\end{array}$ \\
\hline проведенными & 5. Исмаилов К.К. О корреляции межд \\
\hline обо & м дооь \\
\hline $\begin{array}{lcc}\text { диагностировании } & \text { технологического } & \text { состояния } \\
\text { трубопроводов, при помощью которой } & \text { возможно } \\
\text { диагностировать } & \text { внутреннее } & \text { состояние }\end{array}$ & $\begin{array}{l}\text { Материалы } \quad \text { III Всесоюзной науч. } \\
\text { Применение } \\
\text { вероятно-статистических } \\
\text { бурении нефтедобыче. Баку, 1981, С.65. }\end{array}$ \\
\hline
\end{tabular}
трубопроводов при перекачке смесей природных и

\title{
ОЧИСТКА СТОЧНЫХ ВОД ОТ ИОНОВ ТЯЖЕЛЫХ МЕТАЛЛОВ С ПОМОЩЬЮ СОРБЕНТОВ.
}

Петухова Ю.Н. студентка 4 курса кафедры мембранной технологии факультета инженерной химии, Российский Химико-Технологический университет им. Д.И. Менделеева, Российская Федерачия

Ильина С.И.

доцент кафедры прочессов и аппаратов химической технологии, доиент кафедры мембранной технологии, кандидат технических наук,

Российский Химико-Технологический университет им. Д.И. Менделеева, Российская Федерация

Фурсенко А.В. выпускница кафедры мембранной технологии факультета инженерной химии, Российский Химико-Технологический университет им. Д.И. Менделеева, Российская Федерация

Носырев М.A.

доиент кафедры прочессов и аппаратов химической технологии, кандидат технических наук

Российский Химико-Технологический университет им. Д.И. Менделеева, Российская Федерация DOI: $10.31618 /$ ESU.2413-9335.2019.6.64.254

\section{АННОТАЦИЯ}

В работе проведен краткий обзор применения сорбентов из вторичного сырья для извлечения ионов тяжелых металлов из сточных вод. Приведена сравнительная характеристика целлюлозосодержащих сорбентов по сравнению с активированным углем и катионообменными смолами.

\section{ABSTRACT}

The paper provides a brief overview of the use of sorbents from secondary raw materials for the extraction of heavy metal ions from wastewater. The comparative characteristic of cellulose sorbents in comparison with activated carbon and cation exchange resins is given.

Ключевые слова: сточные воды, сорбенты, биополимеры

Key words: waste water, sorbents, biopolymers

В настоящее время одной из важных проблем является утилизация отходов. Причем этот вопрос требует решения во всех отраслях народного хозяйства. 
Деятельность мног пох промышленных предприятий часто приводит к загрязнению окружающей среды сточными водами, содержащие в своём составе вредные вещества, оказывающие и в небольших количествах довольно серьёзное негативное воздействие на здоровье человека и состояние биосферы в целом [1].

Весьма опасными токсинами в сточной воде считаются ионы тяжелых металлов (ИТМ), а также их соединения [2, 3]. Они содержатся в сточных водах гальванических цехов, предприятий машиностроения и металлообработки, рудного и шахтного производства, чёрной и цветной металлургии, химической и нефтехимической промышленности и других отраслей [4].

Вред тяжёлых металлов для живого организма обусловлен их способностью к биоаккумуляции и концентрированию при движении по трофической цепи, что приводит к нарушению функционирования систем органов. Сложность удаления из организма ИТМ вызвано тем, что они образуют прочные связи с белками и другими компонентами клеточных структур [5]. В связи с этим очистка сточных вод промышленных предприятий должна осуществляться до практически полного удаления тяжелых металлов. Но используя лишь традиционные методы этого сложно достичь.

Одним из распространённых способов очистки сточных вод от ИТМ являются сорбционные и ионообменные методы. В связи с этим возрастает необходимость получения более дешёвых сорбентов с улучшенными физикохимическими и эксплуатационными характеристиками. В основном, сорбенты, используемые в промышленности, разрабатываются на основе активных углей. Также интерес представляют сорбенты, изготовленные из вторсырья. Такие материалы могут решить помимо проблемы очистки воды и другую задачу, а именно, утилизацию отходов [7].

Создание достаточно эффективных и безопасных с экологической точки зрения сорбентов и технологий осуществимо за счет образования на полисахаридных полимерах новых функциональных групп, прочно связывающих ионы тяжелых металлов [8]. Подобным образом получают так называемые биополимерные сорбенты. Сырьё, применяемое для сорбции ИТМ, представлено неограниченным набором различных материалов растительного происхождения шишками, опилками, листьями, семенами, плодами и стеблями различных растений, корой лиственных и хвойных пород деревьев, жмыхами и шротами, скорлупой орехов, шелухой, свекловичным жомом, кожурой фруктов, соломой, травянистыми и водными растениями, торфом. А также илом, морскими водорослями, биомассой бактерий, дрожжей; грибов, и др. [9-11]. Здесь стоит отметить, что важным направлением создания биополимерных сорбентов представляется модифицирование структуры природного целлюлозосодержащего сырья, вызывающее иммобилизацию на целлюлозной матрице новых сорбционно-активных центров, являющихся фрагментами комплексонов. Это повышает их селективность, сорбционную емкость и уменьшает время сорбции [8].

При этом некоторые целлюлозосодержащие сорбенты обладают сравнительно низкой емкостью по отношению к ИТМ, другие же по своим свойствам вполне могут быть сопоставимы или даже превосходить применяемые в промышленности ионообменные смолы. Значения величин сорбционной емкости различных целлюлозосодержащих растительных сорбентов в сравнении с величинами сорбционной емкости активированного угля и некоторых ионообменных смол приведены в таблице 1 . 
Таблица 1

АДСОРБЦИОННАЯ СПОСОБНОСТЬ ЦЕЛЛЮЛОЗОСОДЕРЖАЩИХ СОРБЕНТОВ ПО СРАВНЕНИЮ С АКТИВИРОВАННЫМ УГЛЕМ (АУ) И КАТИОНООБМЕННЫМИ СМОЛАМИ

[12].

\begin{tabular}{|c|c|c|c|c|c|c|c|}
\hline \multirow{2}{*}{ Адсорбент } & \multicolumn{6}{|c|}{ Адсорбционная способность, мг/г } \\
\cline { 2 - 9 } & $\mathrm{Pb}^{2+}$ & $\mathrm{Cu}^{2+}$ & $\mathrm{Zn}^{2+}$ & $\mathrm{Cd}^{2+}$ & $\mathrm{Ni}^{2+}$ & $\mathrm{Hg}^{2+}$ & $\mathrm{Cr}^{6+}$ \\
\hline Гранулированный АУ & 16,58 & 5,08 & - & 3,37 & - & - & - \\
\hline Порошкообразный АУ & 26,94 & 4,45 & - & 3,37 & - & - & - \\
\hline Волокна АУ & 30,46 & 11,05 & - & - & - & - & - \\
\hline Скорлупа арахиса & 30,04 & 8,00 & 8,96 & 5,96 & - & - & - \\
\hline Кукурузные кочерьжки & 8,29 & 7,62 & 1,96 & 8,89 & 13,5 & - & - \\
\hline Кукурузный крахмал & 28,8 & 8,57 & 6,87 & 8,88 & - & - & - \\
\hline Кора сосны & - & 9,46 & - & 14,16 & 6,28 & - & - \\
\hline Кора черного дуба & - & - & - & 29,9 & - & - & - \\
\hline Лигнин & 1865 & - & 95 & - & - & - & - \\
\hline Кора & 182 & - & - & 32 & - & 400 & - \\
\hline Ксантан & 18 & - & - & 33,27 & - & 1,15 & - \\
\hline Листовой перегной & - & - & - & - & - & - & 43 \\
\hline Опилки & - & - & - & - & - & - & 16,05 \\
\hline Хлопок & - & - & - & - & - & 1000 & - \\
\hline Дуолит GТ-73 & 122,25 & 61,60 & 55,59 & 105,66 & 56,94 & - & - \\
\hline Амберлит IRC-718 & 290,08 & 127,00 & 156,96 & 258,32 & - & - & - \\
\hline Амберлит 200 & 352,24 & 88,90 & 85,60 & 224,8 & 129,1 & & - \\
\hline Леватит ТР 207 & 198,9 & 85,09 & 89,60 & 49,46 & 88,05 & - & - \\
\hline
\end{tabular}

Как отмечалось ранее, для улучшения сорбционных свойств вторичное сырье подвергают обработке. В работе [13] показана возможность извлечения ионов тяжелых металлов с помощью сульфокатионитов на основе хлопка (X), пшеничной соломы (C) и камыша (K). Их получают в две стадии. Исходное сырьё без предварительной активации сульфировали концентрированной серной кислотой при комнатной температуре в течении 1 часа при массовом соотношении растительного сырья к $\mathrm{H}_{2} \mathrm{SO}_{4}$, равном 1:9. Затем, варьируя соотношения реагентов, температуру и продолжительность процесса, проводили химическое модифицирование сульфированного продукта глицидилметакрилатом (ГМА). В результате чего были синтезированы иониты сетчатого строения КС-ГМА-Х, КС-ГМА-С и КСГМА-К. При сравнении результатов с данными по сорбции ионов тяжелых металлов (таблица 2) было установлено, что сульфокатионит на основе пшеничной соломы обладает высокими сорбционными и кинетическими свойствами по отношению к ионам $\mathrm{Co}(\mathrm{II})$, а катионообменник, синтезированный из камыша, - к ионам Со(II) и $\mathrm{Zn}(\mathrm{II})$.

СОРБЦИОННЫЕ ХАРАКТЕРИСТИКИ СУЛЬФОКАТИОНИТОВ НА ОСНОВЕ РАСТИТЕЛЬНОГО СЫРЬЯ И ГМА ПО ОТНОШЕНИЮ К ИОНАМ ТЯЖЕЛЫХ МЕТАЛЛОВ [13].

\begin{tabular}{c|c|c|c|c|c}
\hline \multirow{2}{*}{ Катионит } & \multicolumn{5}{|c}{$\mathrm{CE},{\mathrm{M \Gamma} \cdot \Gamma^{-1}}^{2}$} \\
\cline { 2 - 5 } & $\mathrm{Pb}^{2+}$ & $\mathrm{Co}^{2+}$ & $\mathrm{Zn}^{2+}$ & $\mathrm{Cu}^{2+}$ & $\mathrm{Ni}^{2+}$ \\
\hline КС-ГМА-C & 181,2 & 353,6 & 195,6 & 178,6 & 152,8 \\
КС-ГМА-К & 228,0 & 271,2 & 270,2 & 175,1 & 152,8 \\
КС-ГМА-X & 207,2 & 200,4 & 176,4 & 146,0 & 105,6 \\
КУ-2х8 & 372,8 & 236,0 & 195,6 & 338,8 & 152,8 \\
\hline
\end{tabular}

Из таблицы 2 хорошо видно, что параметры сульфокатионитов на основе растительного сырья имеют близкие значения с таким широко используемым катионитом, как КУ-2x8, а некоторые из них даже лучше, чем у общеупотребляемого катионита. 
КС-ГМА-С имеет суммарную обменную ёмкость по катионам $\mathrm{Cu}(\mathrm{II})$ и $\mathrm{Co}(\mathrm{II}) 510$ мл/г из раствора, в которых содержание меди и кобальта составляет соответственно 0,95 и 2,36 г/л. Следовательно, его можно рекомендовать для группового извлечения вышеназванных ионов из промышленных растворов и сточных вод на предприятиях цветной металлургии [13].

Химическое модифицирование целлюлозы для улучшения ее сорбционной емкости по отношению к ионам $\mathrm{Cu}(\mathrm{II}), \mathrm{Ni}(\mathrm{II})$ и $\mathrm{Zn}(\mathrm{II})$ с использованием этилендиамина было проведено в работе [14]. Поскольку у целлюлозы в каждом элементарном звене содержатся гидроксильные группы, они могут реагировать с карбоксильными и аминогруппами различных органических соединений. На основании полученных изотерм сорбции авторы установили, что величины максимальной сорбционной емкости составили $308,2,104,1$ и 69,3 мг/Г для ионов $\mathrm{Ni}(\mathrm{II}), \mathrm{Cu}(\mathrm{II})$ и $\mathrm{Zn}(\mathrm{II})$, соответственно.

Хорошие сорбционные свойства имеет и такой биополимер, как хитозан. Его макромолекулы построены из звеньев 2-ацетамидо-2- дезоксиDглюкопиранозы и 2-амино-2-дезокси-Dглюкопиранозы, сопряженные связью $\beta-(1 \rightarrow 4)$. Новые сорбенты созданы в процессе модифицирования хитозана иминодиянтарной и этилендиамин-диянтарной кислотой. Эксперименты показали, что величины предельной сорбционной емкости для сорбентов, обработанных иминодиянтарной кислотой составили: для $\mathrm{Cu}(\mathrm{II})-113,64$ мг/г, для $\mathrm{Zn}(\mathrm{II})-$ 116,24 мг/г, для $\mathrm{Cd}(\mathrm{II})-133,33$ мг/г, для $\mathrm{Pb}(\mathrm{II})-$ 164,95 мг/г. А для сорбентов, обработанных этилендиамин-диянтарной кислотой: для $\mathrm{Cu}(\mathrm{II})-$ 55,56 мг/г, для $\mathrm{Zn}(\mathrm{II})-107,53 \mathrm{мг} / г$, для $\mathrm{Cd}(\mathrm{II})-$ 122,08 мг/г, для $\mathrm{Pb}(\mathrm{II})-217,39$ мг/г [15].

Таким образом, к изучению процессов сорбции тяжелых металлов природными материалами из возобновляемого сырья полисахаридной природы проявляется большой интерес. Обусловливается это тем, что отходы и побочные продукты агропромышленного комплекса являются перспективными и экономически выгодными сорбентами для очистки от ИТМ водных растворов, имеющих различный состав, начиная от сточных вод промышленных предприятий до природных вод и пищевых систем.

\section{Библиографический список}

1. Евгеньев М.И., Евгеньева И.И. Контроль и оценка экологического риска химических производств. Казань: издательство «Фән» АН РТ, 2007. 207 c.

2. Майстренко В.Н., Хамитов Р.3., Будников Г.К. Эколого-аналитический мониторинг супертоксикантов. М.: Химия, 1996. 319 с.
3. Будников Г.К. Тяжелые металлы в экологическом мониторинге водных систем // Соровский Образовательный журнал. 1998. № 5 С. 23-29.

4. Жмур Н.С. Технологические и биохимические процессы очистки сточных вод на сооружениях с аэротенками. М.: АКВАРОС, 2003. $512 \mathrm{c}$.

5. Кузнецов А.Е., Градова Н.Б., Лушников C.В., Энгельхарт М., Вайссер Т., Чеботарёва М. В. Прикладная экобиотехнология: учебное пособие: в 2 т. Т. 2. М.: БИНОМ. Лаборатория знаний, 2010. $485 \mathrm{c}$.

6. Ергожин Е.Е., Бектенов Н.А., Акимбаева А.М. Полиэлектролиты на основе глицидилметакрилата и его сополимеров. Алматы: Эверо, 2004. - 271 с.

7. Собгайда Н.А., Макарова Ю.А. Влияние природы связующего материала на сорбционные свойства сорбентов, изготовленных из отходов агропромышленного комплекса // Вестник Саратовского государственного технического университета. - 2011. - №1. - С. 41-45.

8. Никифорова Т.Е. Физико-химические основы хемосорбции ионов d-металлов модифицированными целлюлозосодержащими материалами // Автореф. дисс... доктора хим. наук.Иваново, 2010.

9. Sud, D. Agricultural waste material as potential adsorbent for sequestering heavy metal ions from aqueous solutions - A review / D. Sud, G, Mahajan, M.P. Kaur // Bioresource Technology. - 2008. - V. 99. - P. 6017-6027

10. Aydin, H. Removal of copper (II) from aqueous solution by adsorption onto low-cost adsorbents / H. Aydın, Y. Bulut, C. Yerlikaya // J. Environ. Management. - 2008. - V. 87. - P. 37-45.

11. Ho, Y.S. Sorption equilibrium of mercury onto ground-up tree fern / Y.S. Ho, C.C. Wang // J. Hazard. Mater. - 2008. - V. 156. - P. 398-404.

12. Kumar, U. Agricultural products and byproducts as a low cost adsorbent for heavy metal removal from water and wastewater: A review / U. Kumar // Sci. Res. Essays. - 2006. V. 1 (2). - P. 033037.

13. Ергожин Е.Е., Никитина А.И., Кабулова Г.К., Бектенов Н.А. Сульфокатиониты на основе растительного сырья и глицидилметакрилата // Химия растительного сырья, 2013, № 1. - С. 67-72.

14. Torres J.D., Faria E.A. , Prado A.G.S. Thermodynamic studies of the interaction at solid / liquid interface between metal ions and cellulose modified with ethylenediamine // J. Hazard. Mater. B. - 2006. - V. 129. - P. 239-243.

15. Kołodynska, D. Adsorption characteristics of chitosan modified by chelating agents of a new generation / D. Kołodynska // Chem. Eng. J. - 2012. V. 179. - P. 33-43. 